\title{
The effect of exogenous cholesterol and lipid-modulating agents on enterocytic amyloid- $\beta$ abundance
}

\author{
Menuka M. Pallebage-Gamarallage ${ }^{1,2,3}$, Susan Galloway ${ }^{2,3}$, Russell Johnsen ${ }^{4,5}$, Le Jian ${ }^{2,3}$, \\ Satvinder Dhaliwal ${ }^{2,3}$ and John C. L. Mamo ${ }^{2,3 *}$ \\ ${ }^{1}$ School of Biomedical Sciences, Curtin University of Technology, Perth, WA, Australia \\ ${ }^{2}$ School of Public Health, Curtin University of Technology, Perth, WA, Australia \\ ${ }^{3}$ Australian Technology Network, Centre for Metabolic Fitness, Perth, WA, Australia \\ ${ }^{4}$ Center for Neuromuscular and Neurological Disorders, University of Western Australia, WA, Australia \\ ${ }^{5}$ The Australian Neuromuscular Research Institute, Nedlands, WA, Australia \\ (Received 12 December 2007 - Revised 23 April 2008 - Accepted 29 April 2008 - First published online 17 July 2008)
}

Dietary cholesterol may influence Alzheimer's disease risk, because it regulates the synthesis of amyloid- $\beta$. It was recently demonstrated in enterocytes of wild-type mice that intracellular amyloid- $\beta$ expression is enhanced in response to a high-fat diet made up of SFA and cholesterol. Intestinally derived amyloid- $\beta$ may be associated with postprandial lipoproteins in response to dietary fats and could be a key regulator in chylomicron metabolism. The present study was designed to investigate the role of cholesterol in modulating amyloid- $\beta$ abundance in enterocytes. Wild-type mice were fed a low-fat diet supplemented with $2 \%(\mathrm{w} / \mathrm{w})$ cholesterol. The effects of cholesterol absorption inhibition and cholesterol biosynthesis inhibition utilising ezetimibe and atorvastatin, respectively, were also studied. Quantitative immunohistochemistry was utilised to determine enterocytic amyloid- $\beta$ homeostasis. We found that enterocytic amyloid- $\beta$ concentration was significantly attenuated in mice fed the $2 \%(\mathrm{w} / \mathrm{w})$ cholesterol diet. However, blocking cholesterol absorption reversed the cholesterol-feeding effect. Consistent with a suppressive effect of cholesterol on enterocytic amyloid- $\beta$ abundance, atorvastatin, an inhibitor of cholesterol biosynthesis, enhanced amyloid- $\beta$. However, providing exogenous cholesterol abolished the atorvastatin-induced effect. In contrast to the suppression of enterocytic amyloid- $\beta$ by dietary cholesterol, mice fed a diet enriched in SFA had markedly greater abundance. Collectively, the findings suggest that exogenous and endogenous cholesterol reduce amyloid- $\beta$ concentration in enterocytes by suppressing production, or enhancing secretion associated with postprandial lipoproteins. Intestinally derived amyloid- $\beta$ will contribute to the pool of plasma protein and may influence cerebral amyloid homeostasis by altering the bi-directional transfer across the blood-brain barrier.

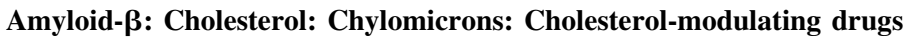

Amyloid- $\beta$ (A $\beta)$ is the main component of proteinaceous deposits found in the brain tissue of subjects with Alzheimer's disease $^{(1)} . A \beta$ is a polypeptide of thirty-nine to forty-three amino acids produced from proteolytic cleavage of the $A \beta$ protein precursor $(\mathrm{A} \beta P \mathrm{P})^{(2,3)}$ by sequential action of $\beta$ - and $\gamma$-secretases ${ }^{(3,4)}$. Cleavage of A $\mathrm{APP}$ within the $A \beta$ domain at amino acid 17 by the $\alpha$-secretase pathway will alternatively generate a membrane-bound carboxyl-terminal derivative, which is non-pathogenic ${ }^{(3)}$. Historically, $A \beta$ generation was thought to occur only at the cell membrane ${ }^{(5,6)}$. However, cellculture studies have shown that $A \beta$ is also generated at the endoplasmic reticulum and secreted via the Golgi apparatus ${ }^{(7-9)}$.

The origin of cerebrovascular $A \beta$ deposits is controversial. There is little evidence for increased $A \beta$ production in sporadic, late-onset Alzheimer's disease. Rather, decreased $A \beta$ clearance from the brain has been put forward as one alternative hypothesis ${ }^{(10)}$. A number of studies have also shown in vivo transport of circulating $\mathrm{A} \beta$ across the blood-brain barrier, thereby contributing to total brain parenchymal $A \beta$ load ${ }^{(11)}$. Consistent with the concept of a vascular origin for cerebral $A \beta$ was the finding that intravenous injection of anti-A $\beta-\operatorname{IgG}$ completely blocked the influx of peripheral $A \beta$ across the blood-brain barrier ${ }^{(10)}$. Circulatory $A \beta$ could be derived from vascular smooth muscle cells and endothelial cells $^{(6,12)}$, or from blood platelets ${ }^{(13)}$. However, in recent studies, we also reported that the absorptive epithelial cells of the small intestine have substantial abundance of $A \beta^{(14)}$.

We found that enterocytic $A \beta$ was substantially increased with the ingestion of a diet enriched in saturated fat and cholesterol, but, in contrast, was completely abolished by fasting $^{(14)}$, clearly showing dietary regulation. These findings may provide insight into the mechanisms underlying epidemiological studies and animal feeding studies that have demonstrated a positive relationship between fat intakes and accelerated amyloid pathology in Alzheimer's disease ${ }^{(15-18)}$. It is our contention that dietary fat-induced elevations in plasma $A \beta$ could 
compromise blood-brain barrier integrity, resulting in altered cerebral $\mathrm{A} \beta$ homeostasis and inflammatory sequelae. Our hypothesis is supported by studies in transgenic animal models that over-express the AßPP in neurons ${ }^{(19,20)}$. In these animals, a high-fat diet exacerbates $A \beta$ burden, demonstrating that cerebrovascular deposition is influenced by circulatory effects, irrespective of the actual cellular origin of the $A \beta$ peptide.

Several animal studies suggest that cholesterol is a proamyloidogenic dietary lipid. Rabbits fed $2 \%(\mathrm{w} / \mathrm{w})$ cholesterol have a dramatic increase in intraneuronal $A \beta$ accumulation positively associated with the duration of feeding ${ }^{(18)}$ and this is reversed when exogenous cholesterol is removed from the $\operatorname{diet}^{(21)}$. Similarly, in young double-transgenic APPsw and $P S 1_{\mathrm{M} 146 \mathrm{~V}}$ mice, dietary cholesterol significantly accelerates $A \beta$ deposition $^{(16)}$. In neuronal cells, $A \beta$ production was positively associated with cholesterol availability ${ }^{(18)}$ and, conversely, treatment with cholesterol synthesis or cholesterol esterification inhibitors negatively modulated $\mathrm{A} \beta$ biogenesis $^{(22,23)}$.

Enterocytes at the proximal region of the small intestine are responsible for the absorption of dietary cholesterol, released into the lymphatics primarily as esters associated with chylomicrons ${ }^{(24,25)}$. A number of studies have demonstrated that cholesterol regulates chylomicron biosynthesis ${ }^{(26-28)}$. hence, our previous finding of enhanced $A \beta$ abundance in enterocytes in response to a high-fat dietary regimen could therefore reflect a cholesterol-induced stimulation of $\mathrm{A} \beta$ production. Indeed, several lines of evidence suggest that intestinally derived $\mathrm{A} \beta$ forms part of the chylomicron structure and thereafter serves as a regulatory apolipoprotein ${ }^{(29,30)}$.

In the present study we compared wild-type mice that were maintained on sterol-free $v$. cholesterol-supplemented feed. An additional group of cholesterol-fed mice was also provided with ezetimibe, a potent compound of the 2-azitidinone class of $\operatorname{drugs}^{(31)}$ that inhibits cholesterol absorption ${ }^{(32)}$. Control mice, fed a sterol-free diet, given ezetimibe alone, were used to rule out pleiotropic effects of the agent.

The effects of cholesterol biosynthesis inhibition on enterocytic $A \beta$ abundance was also studied in mice that were given atorvastatin, a potent 3-hydroxy-3-methylglutaryl CoA reductase inhibitor (the rate-limiting step of the cholesterol biosynthetic pathway) ${ }^{(33)}$. Thereafter, we investigated whether the purported effect of statin therapy would be overcome by provision of dietary cholesterol supplementation.

\section{Methods and materials}

\section{Animals and diet conditions}

The animal housing, handling and experimental procedures described for the present study were approved by the Curtin University Animal Experimentation and Ethics Committee. Female wild-type mice (C57BL/6J), aged 6 weeks, were housed in groups and randomly divided into the diet and drug treatment groups (six mice per group). All mice were maintained in a $12 \mathrm{~h}$ light and dark cycle room, at $22^{\circ} \mathrm{C}$ and with free access to water and food. The control low-fat (LF) cholesterol-free group of mice was fed a semi-purified diet (AIN-93M; Glen Forrest Stockfeeds, Perth, Western Australia) containing $4 \%(\mathrm{w} / \mathrm{w})$ as total fat. Cholesterol was incorporated at $2 \%$ (w/w) into the chow pellets in the sterol-supplemented group (SF06-056; Glen Forrest Stockfeeds). Mice treated with ezetimibe (Ezetrol; Schering-Plough Pty Limited, Baulkham Hill, NSW, Australia) also had the drug incorporated into chow at $12 \mathrm{mg} / \mathrm{kg}$ food and atorvastatin (Lipitor; Pfizer, West Ryde, NSW, Australia) was included at a dose of $20 \mathrm{mg} / \mathrm{kg}$ at the time of feed manufacture.

\section{Tissue collection and sample preparation}

The mice were fed with their respective diets for a period of 4 weeks and were weighed weekly. At the end of the intervention period, mice were anaesthetised with phenobarbitone $(45 \mathrm{mg} / \mathrm{kg}$ intraperitoneally) and exsanguinated by cardiac puncture. Blood was collected into EDTA tubes and stored in ice. Plasma was separated by short speed centrifugation at $4^{\circ} \mathrm{C}$ and stored at $-80^{\circ} \mathrm{C}$.

The small intestine was isolated and flushed with chilled PBS (pH 7.4). A $2 \mathrm{~cm}$ segment of the small intestine distal to the duodenum was fixed in $10 \%$ buffered formal saline for a minimum of $24 \mathrm{~h}$, processed and longitudinal segments embedded in paraffin wax. Serial sections of $5 \mu \mathrm{m}$ thick were cut on a microtome and mounted on silanised slides for histology and immunohistochemistry.

\section{Immunohistochemistry}

Intestinal tissue sections $(5 \mu \mathrm{m})$ were deparaffinised, rehydrated and immunohistochemistry analysis was done as previously described $^{(14)}$. Briefly, the sections were exposed to $3 \% \mathrm{H}_{2} \mathrm{O}_{2}$ in methanol for $30 \mathrm{~min}$ to quench endogenous peroxidase activity, washed and incubated in blocking serum $(20 \%$ goat serum) before overnight incubation at $4{ }^{\circ} \mathrm{C}$ with polyclonal rabbit anti-human $\mathrm{A} \beta_{1-40 / 42}$ antiserum (AB5076; Chemicon, Temecula, CA, USA), diluted to $1: 1000$ with $10 \%$ goat serum. We previously established specificity by replacing the primary antibody with an irrelevant serum or with PBS and by competition immunohistochemistry analysis. For the latter, the primary antisera were pre-mixed with solubilised $\mathrm{A} \beta$. Cerebral tissues from transgenic mice (Tg2576sw) expressing familial human $\mathrm{APP}_{695}$ with established plaques were used as positive controls. Slides were washed in PBS and incubated with biotinylated goat anti-rabbit secondary antibody (1:1000 dilution) (E 0432; Dako, Carpinteria, CA, USA), followed by avidin-biotin-peroxidase complex (ABC/HRP) (K 0377; Dako) for $45 \mathrm{~min}$ at room temperature. Positive immunostaining was established with liquid diaminobenzidine plus $(\mathrm{DAB}+)$ substrate chromogen kit (K 3467; Dako). Sections were then counterstained with Harris's haematoxylin.

\section{Quantitative immunohistochemical analysis}

The intensity of immunostaining for $\mathrm{A} \beta$ was quantified as previously described ${ }^{(14,34)}$. Stained sections were observed with an AxioVert 200M microscope (Zeiss, Jena, Germany). Six mice per group were investigated with duplicate tissue blocks prepared for each group. The absorptive epithelial cells of the small intestine were assessed by a blinded investigator from twenty randomly selected villi per intestine, and at least 100 cells in each villus were counted. The intensity of $\mathrm{A} \beta$ immunostaining was graded as negative (0), mild 
$(+1)$, moderate $(+2)$ and intense $(+3)$ at $\times 200$ magnification. The number of cells with different staining intensity was counted for each villus.

\section{Imaging}

Digital images for photomicroscopy were acquired by an AxioCam HRc camera (Zeiss, Jena, Germany). Images were captured under identical settings utilising AxioVision software (version 4.5).

\section{Cholesterol and triacylglycerol analysis}

Plasma cholesterol and TAG were determined in duplicate by enzymic assays (Randox Laboratories Ltd, Crumlin, Co. Antrim, UK) and according to the manufacturer's instructions.

\section{Statistical analysis}

Statistical analysis of correlation between the intensity of $A \beta$ staining and the feeding groups was determined by the $\chi^{2}$ test. Plasma lipid data were analysed by ANOVA to assess the main effects of dietary cholesterol, cholesterol absorption inhibition (by ezetimibe) and cholesterol biosynthesis inhibition (by atorvastatin) and their two-way interactions. Post hoc comparison of means was done if the associated main effect or interaction was statistically significant within the ANOVA procedure. $P$ values $<0.05$ were considered to be statistically significant.

\section{Results}

Body weight and plasma cholesterol and triacylglycerol levels

The body weights post-dietary and drug intervention and plasma lipids are given in Table 1 . The diet and drug interventions were well tolerated. Weight gain was similar for all groups of mice; however, the final body weight of LF mice given atorvastatin was modestly less than the control LF group $(P=0 \cdot 026)$. Furthermore, LF mice given atorvastatin and ezetimibe also had lower final body weights when compared with the cholesterol-supplemented group (highcholesterol; HC). Plasma lipids were not increased in response to dietary cholesterol supplementation, nor significantly influenced by either ezetimibe or atorvastatin. However, the TAG concentration for the $\mathrm{HC}+$ atorvastatin group was slightly lower than the control LF group $(P=0 \cdot 01)$.

The pattern of amyloid- $\beta$ distribution in absorptive epithelial cells of the small intestine of mice

Staining for $A \beta$ in the small intestine is shown in Fig. 1. Positive $A \beta$ staining was observed in absorptive epithelial cells for all groups of mice. A $\beta$ immunostaining was found throughout the villi, increasing with proximity to the intestinal lumen. The $A \beta$ was enriched within the perinuclear region of the enterocytes consistent with the sites of the Golgi apparatus and the rough endoplasmic reticulum, and the overall pattern of $A \beta$ distribution between treatments was similar. A decreasing gradient of $A \beta$ staining was evident from the perinuclear region through the cytoplasm and lacteals.
Table 1. Effect of various feeding regimens on average weight, and serum cholesterol and TAG levels in wild-type mice (C57BL/6J)* (Mean values with their standard errors for six mice per group)

\begin{tabular}{|c|c|c|c|c|c|c|}
\hline \multirow[b]{2}{*}{ Feeding regimen } & \multicolumn{2}{|c|}{ Weight (g) } & \multicolumn{2}{|c|}{$\begin{array}{l}\text { Total serum } \\
\text { cholesterol } \\
\text { (mM) }\end{array}$} & \multicolumn{2}{|c|}{$\begin{array}{l}\text { Serum TAG } \\
(\mathrm{mm})\end{array}$} \\
\hline & Mean & SEM & Mean & SEM & Mean & SEM \\
\hline LF (df 5) & $19 \cdot 20$ & 0.60 & $2 \cdot 50$ & 0.16 & 0.87 & 0.12 \\
\hline $\mathrm{HC}$ (df 5) & $20 \cdot 53$ & 0.67 & $2 \cdot 43$ & 0.12 & 0.53 & 0.04 \\
\hline $\begin{array}{l}\text { LF }+ \text { atorvastatin } \\
\quad(\text { df } 5)\end{array}$ & $18 \cdot 91 \dagger \ddagger$ & 0.20 & $2 \cdot 25$ & 0.05 & 0.55 & 0.02 \\
\hline $\begin{array}{l}\mathrm{LF}+\text { ezetimibe } \\
\text { (df } 5)\end{array}$ & 19.10‡ & 0.24 & 1.94 & 0.29 & 0.61 & 0.13 \\
\hline $\begin{array}{l}\mathrm{HC}+\text { atorvastatin } \\
\quad(\text { df } 5)\end{array}$ & $19 \cdot 98$ & 0.34 & $2 \cdot 70$ & 0.26 & $0.50 \dagger$ & 0.07 \\
\hline $\begin{array}{l}\mathrm{HC}+\text { ezetimibe } \\
\quad(\text { df } 5)\end{array}$ & $20 \cdot 27$ & 0.57 & 1.95 & 0.21 & 0.72 & 0.07 \\
\hline
\end{tabular}

LF, low-fat; HC, high-cholesterol.

* Wild-type mice (C57BL/6J) were randomised to the six different feeding regimens and were fed their respective diets for 4 weeks. Weights and total serum cholesterol and TAG levels at the end of the experiment were compared between the groups with post hoc comparison of means within the ANOVA procedure. The $F$ statistic for weight between all groups is 10.044; for total serum cholesterol, $F$ 2.458; for serum TAG, F2.843.

† Mean value was significantly lower than that of the LF group $(P<0.05)$.

$\ddagger$ Mean value was significantly lower than that of the $\mathrm{HC}$ group $(P<0.05)$.

\section{The effect of dietary cholesterol and the cholesterol} absorption inhibitor ezetimibe on amyloid- $\beta$ abundance in small-intestinal enterocytes

Enterocytic $A \beta$ determined in mice given a sterol-free diet (LF) or a diet containing $2 \%$ cholesterol is shown as Figs. 1 (A) and (B), respectively, and quantitative analysis for the intensity of $\mathrm{A} \beta$ immunostaining is indicated in Fig. 2. Cholesterol-supplemented mice showed a significant reduction in $A \beta$ staining in the perinuclear regions of the absorptive enterocytes in comparison with the LF group $\left(P<0 \cdot 0001\right.$; Pearson's $\chi^{2} 85 \cdot 206$; df 3$)$ and indeed a larger percentage of absorptive epithelial cells had no discernible staining (Fig. 2). The control group had a greater proportion of cells with mild and moderate staining (Fig. 2). In contrast, the majority of absorptive epithelial cells in the cholesterol-fed group showed no $A \beta$ staining.

The inhibition of enterocytic $A \beta$ staining as a consequence of dietary cholesterol supplementation could be reversed by co-treatment with ezetimibe (Fig. 1 (C)). The intensity of perinuclear $\mathrm{A} \beta$ expression was enhanced in comparison with the HC group $\left(P<0.0001\right.$; Pearson's $\chi^{2} 80.215$; df 3$)$ but was not significantly different from the control LF group. Essentially all cells showed mild-moderate staining intensity and the pattern of distribution was unchanged (Fig. 2). To exclude pleiotropic effects independent of cholesterol absorption inhibition, mice were given ezetimibe in the absence of dietary cholesterol supplementation. No significant difference in intensity or distribution of staining was seen when compared with the LF control group (Fig. 1 (F)).

The effect of cholesterol biosynthesis inhibition by atorvastatin and cholesterol supplementation on amyloid- $\beta$ abundance in small-intestinal enterocytes

To explore whether endogenous cholesterol biosynthesis regulates $\mathrm{A} \beta$ abundance in enterocytes, control LF-fed mice were 


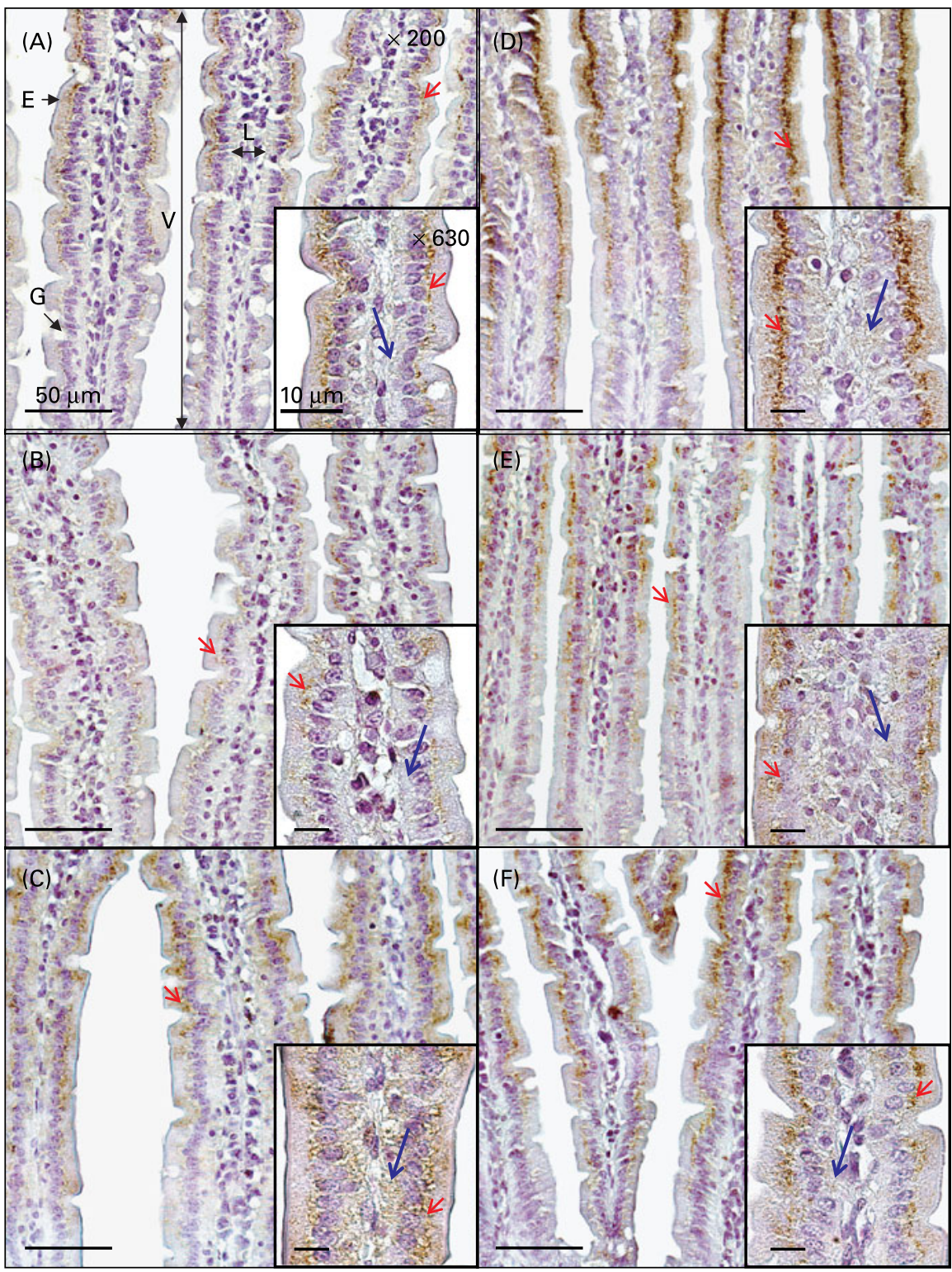

Fig. 1. Amyloid- $\beta(A \beta)$ expression in enterocytes of wild-type mice fed low-fat (LF) (A), high-cholesterol (2\%; HC) $(B)$, $H C+$ ezetimibe (C), LF + atorvastatin (D), $\mathrm{HC}+$ atorvastatin $(E)$ and $L F+$ ezetimibe $(F)$ dietary regimens for 4 weeks. Intestinal sections showing villi at increasing magnification show the pattern of $A \beta$ distribution in the absorptive epithelial cells of the small intestine. A significant amount of $A \beta$ (red arrow) was found concentrated within the perinuclear region of the absorptive enterocytes. A $\beta$ staining was also visible in the lacteals (blue arrow). A $\beta$ concentration was attenuated in $\mathrm{HC}$-fed mice when compared with the LF mouse group, free of drug treatment (see also Fig. 2). The intensity of $A \beta$ staining was enhanced in the HC + ezetimibe group compared with the HC group. Furthermore, atorvastatin increased $A \beta$ immunostaining in the LF group. Large frames: magnification $\times 200$; scale bar $50 \mu m$. Inset frames: magnification $\times 630$; scale bar $10 \mu \mathrm{m}$. E, enterocyte; G, goblet cell; L, lacteal; V, villus.

treated with atorvastatin (Fig. 1 (D)). We found a pronounced increase in staining intensity as a consequence of atorvastatin treatment, with approximately $20 \%$ of enterocytes having intense colouration and the remainder with moderate to mild staining $\left(P=0.016\right.$; Pearson's $\chi^{2} 7 \cdot 409$; df 3$)$ (Fig. 2). To indirectly explore if the atorvastatin-induced effect in $\mathrm{A} \beta$ staining was as a consequence of decreased cellular cholesterol abundance, another group of mice was given atorvastatin concomitant with dietary cholesterol. Exogenous cholesterol was found to significantly attenuate but not completely normalise the atorvastatin-mediated effect (Fig. $1(\mathrm{E})$ ). A large proportion of cells showed no $\mathrm{A} \beta$ staining $(60 \%)$, with essentially the remainder being classified as mild intensity (Fig. 2).
The effect of saturated fat feeding on amyloid- $\beta$ abundance in small-intestinal enterocytes

To explore whether it was the SFA component of the diet which induced enterocytic $A \beta$ accumulation previously reported ${ }^{(14)}$, another group of mice were fed sterol-free chow supplemented with $20 \%$ saturated fats. Figure 3 shows substantially exaggerated $\mathrm{A} \beta$ in the enterocytes of the mice given saturates.

\section{Discussion}

We reported that wild-type mice given a diet enriched in saturated fat and cholesterol had substantially greater 


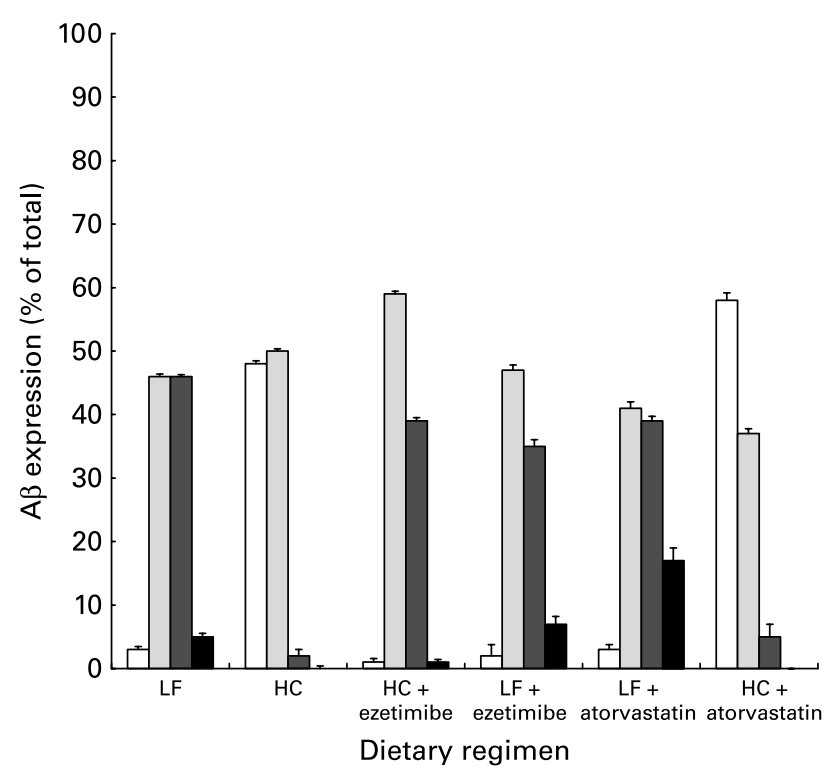

Fig. 2. Semi-quantitative analysis of enterocytic amyloid- $\beta(A \beta)$ expression in six mouse groups fed individual dietary regimens. The histogram shows the number of enterocytes ( $y$ axis), as a percentage of the total cell count, and the intensity of $A \beta$ signal ( $x$ axis) in mice fed low-fat (LF), high-cholesterol (HC), $\mathrm{HC}+$ ezetimibe, LF + ezetimibe, LF + atorvastatin and $\mathrm{HC}+$ atorvastatin dietary regimens. Values are means, with their standard errors represented by vertical bars. $P$ value was determined with the $\chi^{2}$ test and $P<0.05$ considered significant. Staining intensity was considered negative when there was no immunostaining $(0 ; \square)$ and positive when mild $(1+; \square)$, moderate $(2+; \square)$ and intense $(3+; \boldsymbol{\square}) A \beta$ staining was generated. Mice fed cholesterol had attenuated $A \beta$ expression when compared with the LF group $(P<0.0001$; Pearson's $\chi^{2}$ 85.206; df 3). A $\beta$ expression was restored in cholesterol-supplemented mice given ezetimibe $(\mathrm{HC}+$ ezetimibe $v$. $\mathrm{HC})$. Moreover, the atorvastatin-mediated increase in $A \beta$ immunostaining in LF mice, compared with the LF diet group, was abolished by exogenous cholesterol feeding.

enterocytic $A \beta^{(14)}$. To explore if this observation was specifically in response to dietary cholesterol, in the present study we determined enterocytic $A \beta$ expression in 6-week-old female wild-type mice given a LF diet free of saturated fat but supplemented with cholesterol. The effect of cholesterol on enterocytic $A \beta$ homeostasis was also investigated by pharmacologically blocking dietary cholesterol absorption and endogenous cholesterol biosynthesis.

For all groups of mice, the majority of $A \beta$ immunostaining was found concentrated within the perinuclear region of the enterocytes as previously reported ${ }^{(14)}$. The distribution was reminiscent of cell-culture studies, which showed substantial $\mathrm{A} \beta$ within the endoplasmic reticulum and the Golgi apparatus $^{(7-9)}$. The enterocytic perinuclear $A \beta$ distribution is

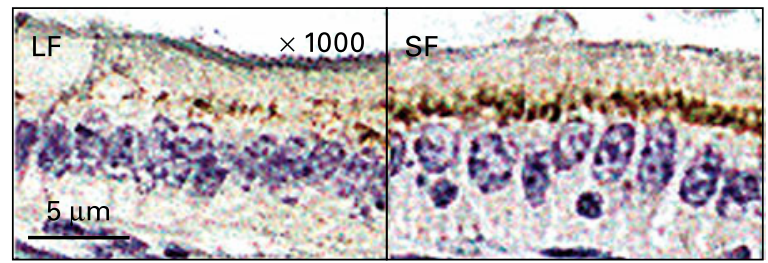

Fig. 3. Amyloid- $\beta(A \beta)$ expression in enterocytes of wild-type mice fed low-fat (LF) and $20 \%$ saturated fat (SF) diets. The enterocytes of mice given a LF diet had modest $A \beta$ abundance within the perinuclear region of the cell compared with mice given a SF-enriched diet. Staining for $A \beta$ is shown at high magnification $(\times 1000$; scale bar $5 \mu \mathrm{m})$ in brown and the cell nuclei in blue. consistent with the sites of chylomicron production and we previously hypothesised that high-fat feeding stimulates $A \beta$ secretion in association with nascent lymph chylomicrons ${ }^{(14)}$.

In contrast to our hypothesis, in the present study we demonstrate that enterocytic $A \beta$ concentration was attenuated in response to cholesterol feeding. Our findings are consistent with that of Howland et al. ${ }^{(35)}$, who established that exposure to increased dietary cholesterol resulted in a significant reduction in the brain level of $A \beta_{1-40 / 42}$ in $A \beta P P$ genetargeted mice. In the present study, reduced enterocytic $A \beta$ abundance as a consequence of cholesterol feeding may be a reflection of attenuated $\mathrm{A} \beta$ biosynthesis and/or enhanced secretion, probably associated with intestinally derived lipoproteins ${ }^{(30)}$. Consistent with the latter, exogenous cholesterol has been found to stimulate chylomicron biogenesis and secretion ${ }^{(28)}$. Our previous studies showed increased cellular $A \beta^{(14)}$ in response to high saturated fat and cholesterol feeding. In the present study, we confirm that saturated fat feeding induces enterocytic $A \beta$ accumulation.

The attenuation of enterocytic $A \beta$ accumulation in cholesterol-supplemented mice could be abolished by the administration of ezetimibe, which effectively suppresses cholesterol absorption $^{(36)}$. Changes in plasma cholesterol concentration were not observed with cholesterol feeding and ezetimibe treatment; however, enterocytic abundance of cholesterol may nonetheless have occurred. There was no difference in enterocytic A $\beta$ staining intensity in mice given cholesterolfree chow plus ezetimibe, suggesting that no pleiotropic effects occurred with this agent.

The suppressive effect of dietary cholesterol on enterocytic $\mathrm{A} \beta$ abundance occurred in the absence of significant changes of plasma cholesterol, indicating that the dose of sterol provided was within physiologically tolerable limits. This contrasts with our previous studies with mice given saturated fats plus cholesterol ${ }^{(14)}$ and studies by others ${ }^{(15,35)}$ where higher doses of sterol supplementation significantly increased plasma cholesterol concentration. The absence of significant changes in plasma cholesterol homeostasis with an attenuation of enterocytic $A \beta$ is consistent with the concept of reduced $A \beta$ production, rather than enhanced secretion associated with chylomicrons. Collectively, these data support the notion that exogenous cholesterol plays an important role in $\mathrm{A} \beta$ homeostasis in the absorptive epithelial cells of the small intestine.

To explore whether endogenous cholesterol biosynthesis regulates enterocytic $A \beta$ homeostasis, mice were given atorvastatin, a potent cholesterol biosynthesis inhibitor. Consistent with the findings of exogenous cholesterol attenuating $A \beta$ concentration in enterocytes, we found that inhibiting cholesterol synthesis with atorvastatin significantly enhanced $A \beta$. Our findings are an extension on the findings by Park et al. ${ }^{(37)}$ who demonstrated cholesterol biosynthesis inhibition by lovastatin increased $A \beta$ generation in the brain tissues of female transgenic mice with familial Alzheimer's disease.

In the present study, we cannot ascertain the mechanism for the atorvastatin-induced effect. Plasma cholesterol, whilst not changed in LF mice given atorvastatin, is a poor surrogate marker of epithelial cell cholesterol homeostasis, because plasma cholesterol is mainly of hepatic origin. However, clues as to whether the atorvastatin effect was pleiotropic are indicated when the drug was co-administered with 
exogenous cholesterol ( $\mathrm{HC}+$ atorvastatin). We observed that dietary cholesterol abolished the atorvastatin effect on enterocytic $\mathrm{A} \beta$ homeostasis, consistent with this agent regulating enterocytic $A \beta$ concentration via modulation of enterocytic pools of cholesterol.

Mechanisms by which dietary cholesterol inhibits enterocytic $A \beta$ concentration are not readily explained. Frears et al. ${ }^{(38)}$ observed that in the presence of cholesterol, human A $\beta P P$ transfected human embryonic kidney (HEK) cells secrete greater quantities of $\mathrm{A} \beta$. In contrast, Abad-Rodriguez et al. ${ }^{(39)}$ showed that upon lowering cholesterol, A $\beta$ generation was increased in primary cell cultures of rat embryo hippocampal neurones and also identified that a moderate reduction in membrane cholesterol resulted in increased $\beta$-secretase. When cholesterol was added back to the cell-culture medium, $\beta$-secretase level returned to a similar level as the control. In animal model studies, enhanced intracellular $\mathrm{A} \beta$ accumulation was evident in brain tissues of cholesterolfed rabbits ${ }^{(18)}$, but this probably reflected deposition rather than intracellular abundance. Increased cerebral $A \beta$ deposition was also reported in TgAPPsw mice with dietary induced hypercholesterolaemia ${ }^{(17)}$, but intestinal $A \beta$ expression in this animal model system has not been reported. Our findings suggest that reduced cholesterol availability enhances enterocytic $\mathrm{A} \beta$ abundance by enhancing its production.

Increased cellular cholesterol could act to increase membrane rigidity of intracellular compartments and thereby block accessibility of secretases to $\mathrm{A} \beta \mathrm{PP}^{(39)}$. Furthermore, intracellular distribution between non-esterified cholesterol in the membrane and cholesteryl esters in the cytoplasm may be important in modulating $A \beta$ homeostasis by alternative mechanisms. Inhibition of cholesterol trafficking in neuronal cells decreased $\beta$-secretase but enhanced $\gamma$-secretase processing of $\mathrm{A} \beta \mathrm{PP}^{(40)}$. The substantial increase in $\gamma$-secretase resulted in an increased concentration of intracellular $A \beta^{(40)}$. It is possible that an alteration in subcellular cholesterol distribution might induce changes in the cell membranes of intracellular compartments, endoplasmic reticulum and Golgi apparatus, and re-localise the enzymes responsible for $\mathrm{A} \beta$ production. Cholesteryl esters also appear pivotal to chylomicron biogenesis ${ }^{(24,25)}$ and may influence secretion of $A \beta$ by modulating release of the native particles. Moreover, there is some evidence of reciprocal modulation of acyl-coenzyme A:cholesterol acyltransferase and $\mathrm{A} \beta$ biosynthesis in cultured cell models $^{(41)}$.

The findings of the present study could suggest that cholesterol absorption inhibitors and 3-hydroxy-3-methylglutaryl CoA reductase inhibitors would lead to higher intestinal A $\beta$ concentrations and therefore to a higher risk of Alzheimer's disease. However, the present study is not designed to consider the potential benefits or risks associated with the use of cholesterol-modulating agents on Alzheimer's disease risk. Inhibitors of 3-hydroxy-3-methylglutaryl CoA reductase reduce CVD and exhibit pleiotropic effects independent of lipid modification and, similarly, some lipid-modulating agents may improve outcome or ameliorate symptoms of neurological disorders ${ }^{(23,42)}$. Nonetheless, the appropriateness of initiating statin therapy is not presently established ${ }^{(43)}$. Elevated total cholesterol, LDL and TAG with normal HDL and total-cholesterol:HDL ratio characterise the lipid profile in Alzheimer's disease. However, scores on the mini mental-state examination do not correlate with lipid parameters, suggesting no interaction between cholesterol and cognition in Alzheimer's disease ${ }^{(44)}$. On the other hand, population studies support a role of dietary fats in Alzheimer's disease. Laitinen et al. ${ }^{(45)}$ reported that intake of unsaturated fats is protective, whereas intake of saturates increases the risk of Alzheimer's disease. In the Framingham study, the top quartile of plasma DHA was associated with a $47 \%$ reduction in risk of all-cause dementia ${ }^{(46)}$. Furthermore, evidence continues to come from animal studies including that of Oksman et el. ${ }^{(47)}$, which confirmed that saturates increased, while DHA decreased, $A \beta$ levels compared with a soya oil diet. Also, in cell-culture studies, fatty acids increased presenilin $1, \gamma$-secretase and $A \beta$ independent of any increase in cellular cholesterol $^{(48)}$. Investigating the putative effects of dietary fatty acids on intestinal $A \beta$ homeostasis may be worthwhile exploring.

Collectively, the findings of the present study indicate that enterocytic $A \beta$ concentration is differentially regulated by dietary cholesterol and saturated fats. Dietary induced changes in production and secretion of $A \beta$ may influence the net circulating pool of $A \beta$ and, possibly, bi-directional kinetics of $A \beta$ across the blood-brain barrier.

\section{Acknowledgements}

The authors declare no conflict of interest. The present study was financially supported by the Australian Technology Network Centre for Metabolic Fitness (Curtin University node).

M. M. P.-G. contributed to experimental data collection and to the writing of the manuscript. S. G. contributed to experimental data collection and to the writing of the manuscript. R. J. contributed to the development of methods and to the writing of the manuscript. L. J. contributed to the project concept, experimental design and to the writing of the manuscript. S. D. contributed to the experimental design and statistical assessment. J. C. L. M. contributed to the project concept, research funding, experimental design, data collection and to the writing of the manuscript.

\section{References}

1. Selkoe DJ (1994) Cell biology of the amyloid $\beta$-protein precursor and the mechanism of Alzheimer's disease. Annu Rev Cell Biol 10, 373-403.

2. Fukuoka A, Nakayama H \& Doi K (2004) Immunohistochemical detection of $\beta$-amyloid and $\beta$-amyloid precursor protein in the canine brain and non-neuronal epithelial tissues. J Protein Folding Disord 1, 173-178.

3. Golde TE \& Eckman CB (2001) Cholesterol modulation as an emerging strategy for the treatment of Alzheimer's disease. Drug Discov Today 6, 1049-1055.

4. Haass C, Hung AY, Schlossmacher MG, Oltersdorf T, Teplow DB \& Selkoe DJ (1993) $\beta$-Amyloid peptide and a 3-kDa fragment are derived by distinct cellular mechanisms. J Biol Chem 268, 3021-3024.

5. Golde TE, Estus S, Younkin LH, Selkoe DJ \& Younkin SG (1992) Processing of the amyloid protein-precursor to potentially amyloidogenic derivatives. Science 255, 728-730.

6. Haass C, Koo EH, Mellon A, Hung AY \& Selkoe DJ (1992) Targeting of cell-surface $\beta$-amyloid precursor protein to lysosomes: alternative processing into amyloid-bearing fragments. Nature 357, 500-503. 
7. Greenfield JP, Tsai J, Gouras GK, Hai B, Thinakaran G, Checler F, Sisodia SS, Greengard P \& Xu H (1999) Endoplasmic reticulum and trans-Golgi network generate distinct populations of Alzheimer $\beta$-amyloid peptides. Neurobiol 96, 742-747.

8. Turner RS, Suzuki N, Chyung ASC, Younkin SG \& Lee WMY (1996) Amyloids $\beta 40$ and $\beta 42$ are generated intracellularly in cultured human neurons and their secretion increases with maturation. J Biol Chem 271, 8966-8970.

9. Wild-Bode C, Yamazaki T, Capell A, Leimer U, Steiner H, Ihara Y \& Haass C (1997) Intracellular generation and accumulation of amyloid $\beta$-peptide terminating at amino acid 42. J Biol Chem 272, 16085-16088.

10. Deane R, Sagare A, Hamm K, Parisi M, LaRue B, Guo H, Wu Z, Holtzman DM \& Zlokovic BV (2005) IgG-assisted agedependent clearance of Alzheimer's amyloid $\beta$-peptide by the blood-brain barrier neonatal $\mathrm{Fc}$ receptor. $J$ Neurosci 25, $11495-11503$.

11. Mackic JB, Bading J, Ghiso J, Walker L, Wisniewski T, Frangione B \& Zlokovic BV (2002) Circulating amyloid $\beta$-peptide crosses the blood-brain barrier in aged monkeys and contributes to Alzheimer's disease lesions. Vascul Pharmacol 38, 308-313.

12. Goldgaber D, Harris HW, Hla T, Maciag T, Donnelly RJ, Jacobsen JS, Vitek MP \& Gajdusek DC (1989) Interleukin 1 regulates synthesis of amyloid $\beta$-protein precursor mRNA in human endothelial cells. Proc Natl Acad Sci U S A 86, 7696-7710.

13. Chen M, Inestrosa NC, Ross GS \& Fernandez HL (1995) Platelets are the primary source of amyloid $\beta$-peptide in human blood. Biochem Biophys Res Commun 213, 96-103.

14. Galloway S, Jian L, Johnsen R, Chew S \& Mamo JCL (2007) $\beta$-Amyloid or its precursor protein is found in epithelial cells of the small intestine and is stimulated by high-fat feeding. J Nutr Biochem 18, 279-284.

15. George AJ, Holsinger RMD, McLean CA, Laughton KM, Beyreuther K, Evin G, Matsters CL \& Li Q (2004) APP intracellular domain is increased and soluble $A \beta$ is reduced with diet-induced hypercholesterolemia in a transgenic mouse model of Alzheimer disease. Neurobiol Dis 16, 124-132.

16. Refolo LM, Malester B, LaFrancois J, Bryant-Thomas T, Wang R, Tint GS, Sambamurti K, Duff K \& Papolla MA (2000) Hypercholesterolemia accelerates the Alzheimer's amyloid pathology in a transgenic mouse model. Neurobiol Dis 7, 321-331.

17. Shie F, Jin L, Cook DG, Leverenz JB \& LeBoeuf RC (2002) Diet-induced hypercholesterolemia enhances brain $\mathrm{A} \beta$ accumulation in transgenic mice. Neuroreport 13, 455-459.

18. Sparks DL, Scheff SW, Hunsaker JC III, Liu H, Landers T \& Gross DR (1994) Induction of Alzheimer-like $\beta$-amyloid immunoreactivity in the brains of rabbits with dietary cholesterol. Exp Neurol 126, 88-94.

19. Giri R, Selvaraj S, Miller CA, Hofman F, Yan SD, Stern D, Zlokovic BV \& Kalra VK (2002) Effect of endothelial cell polarity on $\beta$-amyloid-induced migration of monocytes across normal and AD endothelium. Am J Physiol Cell Physiol 283, C895-C904.

20. LaRue R, Hogg E, Sagare A, Jovanovic S, Maness L, Maurer C, Deane R \& Zlokovic BV (2004) Method for measurement of the blood-brain barrier permeability in the perfused mouse brain. J Neurosci Methods 138, 233-242.

21. Sparks DL (1996) Intraneuronal $\beta$-amyloid immunoreactivity in the CNS. Neurobiol Aging 17, 291-299.

22. Fassbender K, Simons M, Bergmann C, et al. (2001) Simvastatin strongly reduces levels of Alzheimer's disease $\beta$-amyloid peptides $A \beta_{42}$ and $A \beta_{40}$ in vitro and in vivo. Proc Natl Acad Sci U S A 98, 5856-5861.

23. Wolozin B (2004) Cholesterol, statins and dementia. Curr Opin Lipidol 15, 667-672.

24. Shen H, Howles P \& Tso P (2001) From interaction of lipidic vehicles with intestinal epithelial cell membranes to the formation and secretion of chylomicrons. Advanced Drug Del Rev 50, S102-S125.

25. Simons K \& Ikonen E (2000) How cells handle cholesterol. Science 290, 1721-1726.

26. Mahmood-Hussain M (2000) A proposed model for the assembly of chylomicrons. Atherosclerosis 148, 1-15.

27. Cesar TB, Oliveira MRM, Mesquita CH \& Maranhao RC (2006) High cholesterol intake modifies chylomicron metabolism in normolipidemic young men. J Nutr 136, 971-976.

28. Pal S, Allister E, Thomson A \& Mamo JCL (2002) Cholesterol esters regulate $\mathrm{apoB}_{48}$ secretion in $\mathrm{CaCo}_{2}$ cells. Atherosclerosis 161, 55-63.

29. James AP \& Mamo JCL (2005) The immunodetection of lipoprotein-bound amyloid- $\beta$ is attenuated because of the presence of lipids. Ann Clin Biochem 42, 70-72.

30. James AP, Pal S, Gennat HC, Vine DF \& Mamo JCL (2003) The incorporation and metabolism of amyloid- $\beta$ into chylomicron-like lipid emulsions. J Alz Dis 5, 179-188.

31. Sudhop T, Lütjohann D, Kodal A, Igel M, Tribble DL, Shah S, Perevozskaya I \& von Bergmann K (2002) Inhibition of intestinal cholesterol absorption by ezetimibe in humans. Circulation 106, 1943-1948.

32. Davis HR Jr, Zhu L, Hoos LM, et al. (2004) Niemann-Pick C1 Like 1 (NPC1L1) is the intestinal phytosterol and cholesterol transporter and a key modulator of whole-body cholesterol homeostasis. J Biol Chem 279, 33586-33592.

33. Naoumova RP, Dum S, Rallidis L, Abu-Muhana O, Neuwirth C, Rendell NB, Taylor GW \& Thompson GR (1997) Prolonged inhibition of cholesterol synthesis explains the efficacy of atorvastatin. J Lipid Res 38, 1496-1500.

34. Mikaelian I, Nanney LB, Parman KS, et al. (2004) Antibodies that label paraffin-embedded mouse tissues: a collaborative endeavor. Toxic Path 32, 181-191.

35. Howland DS, Trusko SP, Savage MJ, et al. (1998) Modulation of secreted $\beta$-amyloid precursor protein and amyloid $\beta$-peptide in brain by cholesterol. $J$ Biol Chem 273, 16576-16582.

36. Altmann SW, Davis HR, Zhu L, et al. (2004) Niemann-Pick C1 like 1 protein is critical for intestinal cholesterol absorption. Science 303, 1201-1204.

37. Park I, Hwang EM, Honga HS, Boo JH, Oh SS, Lee J, Jung MW, Bang OY, Kim SU \& Mook-Jung I (2003) Lovastatin enhances $A \beta$ production and senile plaque deposition in female Tg2576 mice. Neurobiol Aging 24, 637-643.

38. Frears ER, Stephens DJ, Walters CE, Davies H \& Austen BM (1999) The role of cholesterol in the biosynthesis of $\beta$-amyloid. Neuroreport 10, 1699-1705.

39. Abad-Rodriguez J, Ledesma MD, Craessaerts K, Perga S, Medina M, Delacourte A, Dingwall C, Strooper BD \& Dotti CG (2004) Neuronal membrane cholesterol loss enhances amyloid peptide generation. $J$ Clin Biochem 167, 953-960.

40. Runz H, Rietdorf J, Tomic I, de Bernard M, Beyreuther K, Pepperkok R \& Hartmann T (2002) Inhibition of intracellular cholesterol transport alters presenilin localisation and amyloid precursor protein processing in neuronal cells. J Neurosci 22, 1679-1689.

41. Puglielli L, Konopka G, Pack-Chung E, Ingano LAM, Berezovska O, Hyman BT, Chang TY, Tanzi RE \& Kovacs DM (2001) Acyl-coenzyme A: cholesterol acyltransferase modulates the generation of the amyloid $\beta$-peptide. Nature Cell Biol 3, 905-912.

42. Petanceska SS, DeRosa S, Olm V, Diaz N, Sharma A, ThomasBryant T, Duff K, Pappolla M \& Refolo LM (2002) Statin therapy for Alzheimer's disease: will it work? J Mol Neurosci 19, $155-161$

43. Reiss AB \& Wirkowski E (2007) Role of HMG CoA reductase inhibitors in neurological disorders: progress to date. Drugs 67, 2111-2120. 
44. Sabbagh M, Zahiri HR, Ceimo J, Cooper K, Gaul W, Connor D \& Sparks DL (2004) Is there a characteristic lipid profile in Alzheimer's disease? J Alzheimers Dis 6, 585-589.

45. Laitinen MH, Ngandu T, Rovio S, Helkala EL, Uusitalo U, Viitanen M, Nissinen A, Tuomilehto J, Soininen H \& Kivipelto M (2006) Fat intake at midlife and risk of dementia and Alzheimer's disease: a population-based study. Dement Geriatr Cogn Disord 22, 99-107.

46. Schaefer EJ, Bongard V, Beiser AS, Lamon-Fava S, Robins SJ, Au R, Tucker KL, Kyle DJ, Wilson PW \& Wolf PA (2006) Plasma phosphatidylcholine docosahexanoic acid content and risk of dementia and Alzhimer disease: the Framingham Heart Study. Arch Neurol 63, 1545-1550.

47. Oksman M, Iivonen H, Hogyes E, Amtul Z, Penke B, Leenders I, Broersen L, Lutjohann D, Hartmann T \& Tanila H (2006) Impact of different saturated fatty acid, polyunsaturated fatty acid and cholesterol containing diets on $\beta$-amyloid accumulation in APP/PS1 transgenic mice. Neurobiol Dis 23, 563-572.

48. Liu Y, Yang L, Conde-Knape K, Beher D, Shearman MS \& Shacter NS (2004) Fatty acids increase presenilin-1 levels and $\gamma$-secretase activity in PSwt-1 cells. J Lipid Res 45, $2368-2376$. 